This journal provides immediate open access to its content under the Creative Commons BY 4.0 license. Authors who publish with this journal retain all copyrights and agree to the terms of the above-mentioned CC BY 4.0 license.

DOI: $10.2478 /$ seeur-2020-0003

\title{
THE MASS MEDIA FREEDOM IN A STATE OF EMERGENCY: INFODEMIC VS. COVID-19 PANDEMIC
}

\author{
Asst. Prof. Aneta Stojanovska-Stefanova, $\mathrm{PhD}$ \\ Goce Delchev University - Stip, Republic of North Macedonia \\ aneta.stojanovska@ugd.edu.mk \\ Assoc. Prof. Hristina Runcheva Tasev, $\mathrm{PhD}$ \\ Ss. Cyril and Methodius University - Skopje, Republic of North Macedonia, \\ h.runchevatasev@pf.ukim.edu.mk
}

\begin{abstract}
Information, as well as freedom of expression and freedom of the media are essential for democratic society and fundamental characteristic of modern states. The year 2020 will be remembered as a year of pandemic caused from Covid-19 (coronavirus) and a year of response to unexpected challenge that the spread of the virus caused. In the times of pandemic and any type of crisis, the media always plays a key role in informing the public all over the Globe. This paper aims to make theoretical descriptive research and analysis of the influence of coronavirus on news consumption, the role of media in communication and presentation of important developments during pandemic. The authors present an overview of the media system and the latest developments in the EU in preventing fake news related to the pandemic. We conclude that media plays key role in informing the citizens during pandemic and therefore they have increased responsibility in providing reliable information. At the same time, since the beginning of the Covid-19 pandemic, the media have been challenged with parallel outbreaks of disinformation and misinformation about the virus, ranging from fake coronavirus cures, false claims and harmful health advice to wild conspiracy theories. Disinformation can in turn speed up the spread of disease, hinder effective public health responses, as well as create
\end{abstract}


confusion, fear and distrust. We highlight the fundamental function of creating awareness regarding the topic based on facts, and the need of media for preventing panic and fostering people's understanding by 'checking the source and information twice'.

Key words: media system, pluralism, rumors, fake news.

\section{INTRODUCTION}

The outbreak of coronavirus disease has created a global health crisis that has had a deep impact on the way we perceive our world and our everyday lives. The media played an important role in providing truthful and on time information. Also, freedom of expression and free flow of information are cornerstones of public debate and democracy.

Yet, freedom of expression and the safety of journalists are facing major challenges in Europe today. In many countries, journalists and other media actors are facing threats such as censorship, political and economic pressure, intimidation, job insecurity, abusive use of defamation laws as well as physical attacks. These offences are often committed in an intolerable context of impunity, which fuels recidivism and has a chilling effect on media freedom.

The Coronavirus is not just a medical epidemic. The World Health Organization says fake news about the virus is spreading faster than the disease. Tech companies are attempting to control disinformation. The corona virus is the first epidemic that has received this much attention in the social media age (Mak, 2020). The World Health Organization has described - as a "second disease" accompanying the COVID-19 pandemic - an "infodemic", which is "an overabundance of information - some accurate and some not - that makes it hard for people to find trustworthy sources and reliable guidance when they need it” (WHO, 2020).

Journalism is key to supplying credible information within the wider "infodemic", and to combating the myths and rumours. Without it, false content can run rampant.

Falsehoods in circulation can be categorized as both disinformation (produced and shared with malicious motivation), and misinformation, when these lies are spread without bad intentions. But in the context of COVID-19, the effects of both can be equally deadly (UNESCO, 2020).

The volume and velocity of false information within the "infodemic" points to the existence of a toxic disinfodemic of disinformation and misinformation (Posseti \& Bontcheva). While 
information empowers, the disinfodemic disempowers. It endangers lives and leads to confusion and discord.

Free and independent media are a cornerstone of democratic societies. On the basis of the European Convention on Human Rights and the European Court of Human Rights' case law, member States of the Council of Europe have both negative and positive obligations to protect journalists. It is not only their duty to refrain from intimidating political declarations or judicial practices against media actors, they also need to actively provide them full legal and judicial protection in order to create friendly environment for their journalistic activities.

This is one of the many OSCE's field operations that also pursue activities dedicated to media freedom and development. The OSCE is focused on: monitoring the work of media regulators; monitoring and reviewing the improvement and implementation of media legislation; supporting national reforms in broadcasting; providing technical expertise to national authorities, for example on transitioning from analogue to digital broadcasting; fostering transparency, credibility and independence of media; advising media outlets; organizing training for journalists, law enforcement, lawyers, judges, civil servants, students; monitoring freedom of the media; documenting cases of media rights violations; holding public discussions; and supporting independent media outlets (OSCE, 2020).

Media freedom has increasingly come under the spotlight in recent years. In its 2019 report on media freedom (Repucci, 2019), Freedom House argued that media freedom around the world was coming under growing threat both in democratic and non-democratic countries, whilst in its 2020 edition of the World Press Freedom Index (RSF Index, 2020), Reporters Without Borders (RSF) argue that the next decade will be pivotal in ensuring the preservation of media freedom. This threat to media freedom is often attributed to the recent rise of populist and authoritarian governments, with many world-leaders - including leaders of major democracies - increasingly seeming to view free media as an opponent, rather than a fundamental aspect of a free society. The knock-on effects of such actions can be grave, particularly given the important role that a free media plays in upholding democracy and democratic freedoms. Media freedom and pluralism are part of the rights and principles enshrined in the European Charter of Fundamental Rights and in the European Convention on Human Rights. As the coronavirus pandemic continues to have significant ramifications for public health, social welfare and the economy, the crisis also presents a significant threat to media freedom. Media freedom proponents have warned that governments across the world could use the coronavirus 
emergency as a pretext for the implementation of new, draconian restrictions on free expression, as well as to increase press censorship.

In many countries, the crisis has been exploited for just such reasons, with political leaders using it as a justification for additional restrictions on media freedom. In its 2020 World Press Freedom Index, RSF argues that certain governments have used the crisis to impose media restrictions that in ordinary times would be impossible. The Council of Europe (CoE) Platform for the Protection of Journalists has warned that the fresh assault on media freedom amid the Covid 19 pandemic has worsened an already gloomy media freedom outlook (Bentzen, 2020).

\section{RESTRICTIONS ON FREEDOM OF EXPRESSION AND MEDIA FREEDOM IN A STATE OF EMERGENCY}

Rights and freedoms are basic indicator for the position and role of people in society on one hand, and democratic capacity of the government on the other. They are an instrument to limit the power and disable its arbitrariness and abuse. Free access to information and ideas and by that free expression of views are essential for strengthening the individual dignity and participation in a democratic society.

It is commonly accepted that the right of freedom of expression is at the heart of the whole human rights system and that the level of its protection indicates if the state can be qualified as liberal-democratic. The media has the role of the public watchdog, but the freedom of expression, the transparency and open exchange of opinions and ideas is not unlimited. The limits are often set precisely by the international legal instruments and are activated if other human rights are jeopardized (for example, the right of privacy). Therefore, the media should use their power to keep the balance between different rights in order to respond to the task of keeping the role of the media as a "market place of ideas and opinions" where the free consumers can make the choice. (Runcheva, 2012).

Freedom of public speech and public performance refers to the right of the people to express their thoughts, not only with words but also with other means of expression. Freedom of informing includes free access to information, freedom to receive and communicate information. The Constitution guarantees freedom of establishment of institutions for public information, the right to reply in the means of public informing, the right to protect a source of information in means for public informing and prohibit censorship (Stojanovska-Stefanova et al., 2017b). 
As governments around the world are declaring a state of emergency in response to the Covid19 outbreak, it is of crucial importance to ensure that any introduced measures do not undermine freedom of expression (Article 10) and other human rights enshrined in the European Convention on Human Rights and are "strictly required by the exigencies of the

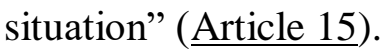

As the risk of disproportionate interference is especially high during times of crisis, governments shall exercise particular prudence and caution to only introduce measures that constitute "an appropriate response to the state of emergency".

In every country, the creation of public opinion occupies a significant place in the public sphere. Authorities, depending on the degree of democracy, type of political system and constitutional order, in their own way tend to create policies in favour of the public opinion in order to govern for a longer period and provide support from the citizens. Knowing that the public opinion creates courts for modus operandi of the community and appreciation for the actions of the government, it is expected that the government seek to impose their influence on the creation of public opinion in order to retain or maintain the power. Public opinion as a form of political consciousness is associated with the political system as an institutional base of the political process (Stojanovska-Stefanova et al.,2017b).

Freedom of expression is a conditio sine qua non for the development of the democratic society where everyone has the right to participate effectively in the process of opinion-making and decision-making procedures. Under no circumstances shall the crisis situation be used by states to claim excessive powers or to limit freedom of expression. Censorship and information control, attempts on media independence, limitations on public access to information and on public scrutiny over governments' actions, restrictions on access of journalists to first-hand information sources, enhanced surveillance measures compromising confidentiality of journalistic sources and other forms of interference all carry direct and tremendous risks for the very foundations of democracy.

However, quality journalism, public debate and cooperation between public authorities and the media could help empower citizens and assist governments in surmounting the unprecedented challenges of the day. The Council of Europe Guidelines on protecting freedom of expression and information in times of crisis (CM/Del/Dec(2007)1005/5.3), the upcoming Committee Recommendation on promoting a favourable environment for quality journalism in the digital age, as well as other Council of Europe standard-setting documents, notably, the Court's case- 
law shall serve as points of reference for Council of Europe member states in finding ways to contain the COVID-19 pandemic without detriment to freedom of expression and other human rights.

\section{RUMORS AND FAKE NEWS VS. FACTS ABOUT COVID-19}

The pandemic Covid-19, was accompanied by various fake news, misinformation and rapid spread of rumours across social media like feathers. They caused panic among people and panic during the decision-making process. The rapid spread of misinformation and stories via social media platforms such as Facebook, YouTube, Twitter etc. became a vital concern of the governments and public health authorities all over the world.

A team of international scientists published study in the American Journal of Tropical Medicine and Hygiene (Islam, M.S., 2020). The scientists looked at data compiled between December 2019 and April 2020 as part of the study. They followed and examined COVID-19related rumours, stigma, and conspiracy theories circulating online, including fact-checking websites, Facebook, Twitter, and online newspapers, and their impacts on public health. The study identified 2,311 reports of rumours. Misinformation about the coronavirus has led to the deaths of at least some 800 people and possibly more.

The results revealed that roughly 800 people died from drinking highly-concentrated alcohol in the hope of disinfecting their bodies, while 5,900 citizens were hospitalized after consuming methanol, with 60 people going blind as a result. Claims were related to illness, transmission and mortality (24\%), control measures (21\%), treatment and cure (19\%), cause of disease including the origin (15\%), violence (1\%), and miscellaneous (20\%). Of the 2,276 reports for which text ratings were available, 1,856 claims were false (82\%).

The report, which analysed data from 87 countries in 25 languages, also found that some Asian citizens and health care workers were repeatedly stigmatized. As a result, they faced increased verbal and physical abuse.

"During the pandemic, there have been repeated accounts of verbal and physical abuse against people of Asian descent, and those involved in healthcare activities," the researchers noted. "Stigmatized people are vulnerable to social avoidance or rejection, poor health-seeking behaviour, and physical violence."

In addition, statistics track trends on fast spread of disinfodemic. The figures are discouraging. 
Based on a machine learning analysis of 112 million public social media posts, in 64 languages, related to the COVID-19 pandemic, researchers at the Bruno Kessler Foundation found that $40 \%$ of posts came from unreliable sources (Infodemics Observatory, 2020). Another study using machine-learning techniques, by the Foundation's COVID-19 Infodemic Observatory, found that almost $42 \%$ of over 178 million tweets related to COVID-19 were produced by bots, and 40\% were "unreliable"(Wilding, 2020). In March, about 40 million problematic posts related to COVID-19 on Facebook were identified (and had warnings placed next to them), according to the company. "Hundreds of thousands of pieces of misinformation about the virus that could lead to imminent physical harm," were also removed, it added (Rossen, 2020). Approximately 19 million out of nearly 50 million (38\%) tweets related to COVD-19 analysed using artificial intelligence by Blackbird.AI were deemed to be "manipulated content". The Coronavirus Facts Alliance has discovered - and disproved more than 3,500 false or misleading pieces of information, in more than 70 countries and in more than 40 languages (Darmanin, 2020).

As a result of their findings, the scientists urged governments and international organizations to better scrutinize the spread of so-called fake news. They called on them to "cooperate with social media companies to spread correct information."(Krishan, 2020).

Medical misinformation and unverifiable content about the COVID-19 pandemic are spreading on social media at an unprecedented pace. Mitigating the advent of rumours and misinformation during the COVID-19 pandemic is crucial, since misinformation and fake news create panic, fear and anxiety among people, predisposing them to various mental health conditions. Instead of considering social media as a secondary medium, it should be utilized to convey important information. Besides, it allows citizens to address their queries directly. Several governments across the world have taken actions to contain the pandemic of misinformation, yet measures are required to prevent such communication complications (Srivastava et al., 2020).

As we said above, the coronavirus pandemic has been accompanied by a massive wave of false and misleading information, attempts by foreign actors to influence domestic debates in the EU, breeding on the fertile ground of people's most basic anxieties and the rapidly changing news cycle. Misleading healthcare information, dangerous hoaxes with false claims conspiracy theories and consumer fraud endanger public health. 
In addition, the Covid-19 Pandemic has rapidly accelerated the hate speech, xenophobia, stigma, discrimination and racism worldwide. The virus of hate has been spreading as fast as the Covid-19 and the immunity of our societies is challenged by the need to be boosted. Stigmatization of certain groups, such as migrants, during crisis situation is not new, but during this pandemic there have been registered broad patterns of hostility towards migrants. People of Asia have been stigmatized for spreading the virus, later xenophobic sentiments were expressed by political leaders, verbal and physical assaults appeared and even institutional exclusion was present at a receiving country of migrants. This drove migrants, according to WHO (Situation Report 35, 2020), to hide their illness to avoid discrimination, to prevent them from seeking immediate health care and even discourage them from adopting healthy behaviours.

The European Union and its Member States are determined (Joint Statement, 2020 March 26) to counter efforts by actors who try to exploit the crisis and put citizens' lives at risk, or who spread propaganda or hatred. The COVID-19 pandemic constitutes an unprecedented challenge for Europe and the whole world. It requires urgent, decisive, and comprehensive action at the EU, national, regional and local levels. The EU member states are determined to do everything that is necessary to protect their citizens and overcome the crisis, while preserving European values and way of life. Building on the 2018 action plan against disinformation, this calls for more coordinated action, in line with our democratic values.

In a Joint Communication, the European Commission and the High Representative propose concrete actions for a stronger and more resilient EU. They will feed into future EU work on disinformation, notably the European democracy action plan, as well as the Digital Services Act (JOIN/2020/8 final). It focuses on how to deal with disinformation both within the EU and in its neighbourhood. Efforts to strengthen the Strategic Communication Task Forces of the European External Action Service play a key role here.

Other actions aim to strengthen coordinated and joint responses to disinformation, to mobilise the private sector to make sure that it delivers on its commitments in this field, and to improve the resilience of society to the challenges that disinformation creates.

The crisis has become a test case showing how the EU and its democratic societies deal with the disinformation challenge (JOIN/2020/8 final).

Today, there are different conceptions of democracy. One would be that in which democratic society possesses means of assistance that could, in some reasonable way, to participate in the 
management of their works and the information would be free and available to all (Chomsky, 2003: 147). The second concept is that, according to Chomsky, the public is banned in the management of its obligations and the information is strictly controlled. It may sound strange, but it is important to know that the second concept is the one that prevails (StojanovskaStefanova et al., 2017a).

\section{A. EXAMPLES OF DISINFORMATION}

A widely circulated social media post claiming to be an "excellent summary" of how to prevent COVID-19 is full of misinformation.

It claims to be from the US-based Johns Hopkins University, which has been at the forefront of publishing up-to-date information about the pandemic, including an interactive map that is often cited by scientists, politicians and journalists alike.

But Euronews has established the post - which includes advice such as using Listerine as a disinfectant - has nothing to do with the university. "This is not something produced by Johns Hopkins Medicine" the university said: "We have seen rumours and misinformation about COVID-19 citing our experts and circulating on social media, and we have received several inquiries from the general public about these posts. We do not know their origin and they lack credibility. There are many concerning elements to this post, according to Dr Jason Kindrachuk, assistant professor of viral pathogenesis at the University of Manitoba. Not only does the post wrongly attribute to a credible source, but there is a grain of truth amid the misinformation. "The issue is what we are seeing is that people are becoming a little bit clever. So, they put in just enough information that is valid to then, for some reason, put in a lot of other theories that really have no sign of relevance," Dr Kindrachuk said (Davis, 2020)".

False claims such as 'drinking bleach or pure alcohol can cure the coronavirus infections': on the contrary, drinking bleach or pure alcohol can be very harmful. Belgium's Poison Control Centre has recorded an increase of $15 \%$ in the number of bleach-related incidents.

Conspiracy theories, such as the claim that coronavirus is 'an infection caused by the world's elites for reducing population growth'. The scientific evidence is clear: the virus comes from a family of viruses originating in animals that include other viruses such as SARS and MERS. Claims that '5G installations would be spreading the virus'. These theories had no specific substantiation and led to attacks on masts (JOIN/2020/8 final). 
False info on Indian social media caused several citizens to drink cow urine or eat dung, in order to prevent infection, while in Saudi Arabia, camel urine with lime was hailed as a protection against the coronavirus.

The scientists also investigated other rumours, such as eating garlic, wearing warm socks and spreading goose fat on one's chest, as treatment for the potentially fatal virus. Conspiracy theories were also monitored, such as the notion that it's a bio-weapon funded by Bill Gates to further vaccine sales.

\section{B. TRANSPARENCY AND THE IMPORTANCE OF REAL TIME INFORMATION}

The differences in mass media in different countries are somewhat a reflection of what people do in different places, as well as the experience which indicates what those citizens want to read. However, there is a greater difference, which is that the press always gets the shape and color of the social and political order in which it acts. The above, in particular reflects the system of social control, which adjusts the relationship between individuals and institutions. In the end, the type of social structure and political system, and the circumstances in which a country is, significantly affecting the development of media freedom (Stojanovska-Stefanova et al., 2017a).

The European Commission has called on tech giants such as Google, Twitter and Facebook to intensify measures to counter fake news about the coronavirus online. To prevent disinformation and raise users' awareness of propaganda, the European Commission will require social media platforms to provide monthly reports about their actions and data related to advertising. Platforms will also be called upon to cooperate more with independent factcheckers in all the EU's member states and in all bloc languages (Nack, 2020).

The Commission and the European External Action Service will further invest in their strategic communication capabilities. To this aim, the European Union has launched its "Team Europe" package to support partner countries in the fight against the coronavirus pandemic and its consequences (EEAS, 2020). The objective of the "Team Europe" approach is to combine resources from the EU, its Member States, and financial institutions, in particular the European Investment Bank and the European Bank for Reconstruction and Development. 
The Commission has launched a dedicated coronavirus response website that provides realtime information on the virus and the EU's response. A dedicated coronavirus disinformation section features regular rebuttals - in all EU languages - of the most prominent coronavirus myths. The Commission promotes content from the World Health Organization, national health authorities and the European Centre for Disease Prevention and Control. The EEAS together with the Commission deployed - and will further strengthen - strategic communications and public diplomacy in the EU's immediate neighbourhood and around the world. The Commission Representations in Member States continues to promote factbased information tailored to the local situation.

Since the outbreak of the crisis, Twitter has seen a $45 \%$ increase in usage of Twitter Moments - curated content that allows for global coronavirus tracking, and challenged more than 3.4 million suspicious accounts targeting coronavirus discussions.

The Facebook and Instagram Info hubs have directed more than 2 billion people to resources from health authorities, including the World Health Organization, through their COVID-19 Information Centre.

Google's YouTube has reviewed over 100,000 videos related to dangerous or misleading coronavirus information and has removed over 15,000 of them.

Microsoft puts in place an information panel on LinkedIn and an updated one-stop shop for news related to the coronavirus called the Daily Rundown, reaching 96 million people daily.

Platforms removed millions of misleading advertisements online about overpriced, ineffective or potentially dangerous products.

\section{RISING CITIZENS AWARENESS AND ENSURING FREEDOM OF EXPRESSION}

Freedom of expression and information and freedom of the media are crucial for the functioning of a democratic society and continue to be so in times of crisis. In times of crisis media plays a key role, also coupled with increased responsibility, in providing accurate, reliable information to the public, but also in preventing panic and fostering people's understanding (CoE, 2020a).

According to article 10 European Convention on Human Rights: "Everyone has the right to freedom of expression". 
The EU's approach to fight disinformation is based on respect for fundamental rights. The coronavirus cannot be used as a pretext to undermine freedom of expression, reduce the accountability of public authorities or unduly limit access to information and transparency. The crisis has demonstrated the essential role of journalists who provide citizens with reliable, factchecked information, that contributing to saving lives.

The Commission has been closely monitoring the impact of emergency measures taken by Member States on EU law and values and will continue to do so until all measures are hased out.

The Commission calls on Member States to intensity efforts to ensure that journalists can work safely, in the right conditions, and make the most of the EU's coronavirus economic response and recovery package to support media while respecting their independence.

The EU will further enhance support to civil society, independent media and journalists around the world and step up actions to increase protection of freedom of expression and a safer media environment (JOIN/2020/8 final).

The media played important role for:

- Freedom of expression and information and media freedom are crucial for the special attention should be paid to the communication and dissemination of information relating to the virus and its circulation, risks of contamination, number of illnesses/deaths, as well as to those measures which have more remote connection with the policy of social distancing/isolation. Related restrictions on the freedom of expression introduced in some States are potentially worrying.

- Media play a key role, also coupled with increased responsibility, in providing accurate, reliable information to the public, but also in preventing panic and fostering people's understanding and cooperation with necessary restriction. Media organisations and journalists should adhere to the highest professional and ethical standards, give priority to authoritative messages regarding the crisis, and refrain from publishing, and thus amplifying, unverified stories.

- Rumours, misinformation and disinformation are more likely to cause harm to the public order and health safety. As exceptional measures required by exceptional circumstances (i.e. to avoid spreading conspiracy theories, false alerts, etc.), some restrictions may be needed and justified. However, States should avoid measures derogating from the guarantees of Article 15 ECHR that are broadly and vaguely worded, lack foreseeability and/or are likely to lead to over criminalisation. In turn, professional journalists should be careful in verifying information coming from nonofficial sources before publishing it, and refrain from publishing implausible/sensationalist materials that could cause panic.

- States should regularly and promptly inform the public about the dimensions and implications of the crisis and the governments' measures, engaging in an open communication that promotes trust and cooperation of every individual. However, the 
flow of information about the pandemic should not be reduced to official communications. This would lead to censorship and suppression of legitimate concerns.

- Journalists and media, medical professionals, along with civil society activists and members of the general public, should have the right to criticise the authorities and scrutinise their response to the crisis. This is particularly important now, when other checks and balances on the government action are removed or eased, especially under emergency measures or even the state of emergency in some states. The heroic story of Li Wenliang, the Chinese whistle-blower doctor (BBC, 2020), shows the danger of suppressing free flow of information of vital importance. Likewise, it is unacceptable to use the epidemic as a pretext to silence the political opponents of the current government.

- Finally, there is hardly any justification for prior censorship of certain topics, closure of media outlets or outright blocking of access to on-line communication platforms. Malicious spreading of disinformation may be tackled with ex post targeted sanctions, and with the governmental information campaigns. States should work together with online platforms and the media to prevent the manipulation of public opinion, as well as to give greater prominence to generally trusted sources of news and information, notably those communicated by public health authorities.

- While it is natural to limit physical public gatherings, on-line forms of civic and communal life must not only be preserved but actively supported by the State (CoE, 2020b). 


\section{CONCLUSION}

According, to all mentioned above, the media have long been recognized as powerful, especially during the health tremendous pandemic. The mass media has a key role in 2019 and 2020 informing about Covid-19 regarding the physical threat, social and physical distancing, as well as public alarm for wearing masks. Also, in the time of crisis, media, especially the social media provide solace or grounds for misinformation, (de)humanization, and discrimination, that hypothetically is violence on human rights. Therefore, we harness the flexibility and ubiquity of media technologies to increase the public's adherence to the safety measures suggested by global health organizations to combat the spread of Covid-19.

Within this framework of complexity, the media have to create effective strategies for helping individuals in dealing with social and physical distancing. The media have to promote adaptive responses to foster positive health attitudes and adherence to preventive measures.

In the future, it is necessary to have developed and implemented effective health and public health communication, during the pandemic having in mind the great impact that both broadcasting and digital media have on the public attitude.

Also, the media have to combat with rumours and fake news by making researches and checking the information twice and to reduce stigma, prejudice, discrimination, and inequalities in public.

Misinformation fuelled by rumours, stigma, and conspiracy theories can have potentially serious implications on the individual and community if prioritized over evidence-based guidelines. Health agencies must track misinformation associated with the COVID-19 in real time, and engage local communities and government stakeholders to debunk misinformation. 


\section{REFERENCES}

- Bennett, W. Lance; Livingston, S. (2018). The disinformation order: Disruptive communication and the decline of democratic institutions. European journal of communication, v. 33, n. 2, pp. 122-139. https://doi.org/10.1177/0267323118760317

- Bennett, W. L. \& Pfetsch, B. (2018). Rethinking political communication in a time of disrupted public spheres. Journal of communication, v. 68, n. 2, pp. 243-253. https://doi.org/10.1093/joc/jqx017

- Blackbird.ai. COVID-19 (Coronavirus) Disinformation Report. Retrieved from: https://www.blackbird.ai/covid-19-disinformation/

- Carlson, M. (2017). Journalistic authority: Legitimating news in the digital era. New York: Columbia University Press. ISBN: 9780231174459

- Casero-Ripollés, Andreu (2018). Research on political information and social media: Key points and challenges for the future. El profesional de la información, v. 27, n. 5, pp. 964974. https://doi.org/10.3145/epi.2018.sep.01

- Casero-Ripolles, Andreu. (2020). Impact of COVID-19 on the Media System. Communicative and Democratic Consequences of News Consumption during the Outbreak Casero-Ripollés, Andreu (2020). El profesional de la información, v. 29, n. 2, e290223. https://doi.org/10.3145/epi.2020.mar.23, Available at SSRN: https://ssrn.com/abstract $=3594133$

- Chadwick, Andrew. (2017). The hybrid media system: Politics and power. Oxford: Oxford University Press. ISBN: 9780190696733

- Dahl, Robert A. (2006). On political equality. New Haven: Yale University Press. ISBN: 978 0300126877

- Habermas, Jürgen. (2006). Political communication in media society: Does democracy still enjoy an epistemic dimension? The impact of normative theory on empirical research. Communication theory, v. 16, n. 4, pp. 411-426. https://doi.org/10.1111/j.14682885.2006.00280.x

- Islam, M.S. Sarkar, T. Khan, S.H. et al.(2020) COVID-19-Related Infodemic and Its Impact on Public Health: A Global Social Media Analysis. The American Journal of Tropical Medicine and Hygiene. DOI: https://doi.org/10.4269/ajtmh.20-0812

- Posseti, J \& Bontcheva, K. Combating the disinfodemic: Working for truth in the time of COVID-19, UNESCO. Retrieved from:

https://en.unesco.org/sites/default/files/disinfodemic_deciphering_covid19_disinformation.pd $\underline{f}$.

- Rosen, G. (2020, April 16). VP Integrity, An Update on Our Work to Keep People Informed and Limit Misinformation About COVID-19. Retrieved from: https://about.fb.com/news/2020/04/covid-19-misinfo-update/

- Runcheva, H. (2012). Protecting the Freedom of Expression: Between the European Convention and the EU Charter. Political Thought 38(2012): 95-102. Skopje: Konrad Adenauer Foundation. Retrieved from: http://www.kas.de/wf/doc/kas_31334-1522-130.pdf?121230203707 
- Srivastava, K.C. at all, Facade of media and social media during COVID-19: A review. Retrieved from: https://pharmascope.org/ijrps/article/view/2288/4482, DOI: https://doi.org/10.26452/ijrps.v11iSPL1.2288.

- Stojanovska-Stefanova, A. Atanasoski, D. and Chacorovski, Z. (2017a). Democracy and media-Types of theories for means of mass communication. US China Law Review, 14 (6). pp. 363-376. ISSN 1548-6605, DOI: 10.17265/1548-6605/2017.06.003

- Stojanovska-Stefanova, A. Atanasoski, D. and Chacorovski, Z. (2017b). Influence of the politics of the freedom of the media. US China Law Review, 14 (5). ISSN 15486605, pg.311320, DOI:10.17265/1548-6605/2017.05.00

- UNESCO (2020) Journalism, 'Fake News' and Disinformation: A Handbook for Journalism Education and Trainin. Retreived from: https:/len.unesco.org/fightfakenews

\section{DOCUMENTS AND CONVENTIONS IN ELECTRONIC FORM (PDF)}

- Council of Europe. (2020a). Mitigating a global health crisis while maintaining freedom of expression and information. Retrieved from: https://rm.coe.int/en-mitigating-a-global-healthcrisis-while-maintaining-freedom-of-expr/16809e2d1e

- Council of Europe. (2020b). Freedom of expression and information in times of crisis.

Retreived from: https://www.coe.int/en/web/freedom-expression/freedom-of-expression-andinformation-in-times-of-crisis

- European Parliament (2020). The impact of coronavirus on media freedom. Retrieved from: https://www.europarl.europa.eu/RegData/etudes/BRIE/2020/651905/EPRS_BRI(2020)65190 5_EN.pdf

- European Convention on Human Rights. Retreived from: https://www.echr.coe.int/Documents/Convention_ENG.pdf.

- CM/Del/Dec(2007)1005/5.3 (2007, October 1) Guidelines of the Committee of Ministers of the Council of Europe on protecting freedom of expression and information in times of crisis. Retrieved from: https://search.coe.int/cm/Pages/result_details.aspx?ObjectID=09000016805ae60e\#_blank

- JOIN (2018) 36 final. (2018, December 5). Action Plan Against Disinformation. Retreived from: https://ec.europa.eu/commission/sites/beta-political/files/eu-communicationdisinformation-euco-05122018 en.pdf

- JOIN/2020/8 final. (2020, June 10). Tickling the coronavirus disinformation. European Commission. Retreived from: https://ec.europa.eu/info/live-work-traveleu/health/coronavirus-response/fighting-disinformation/tackling-coronavirusdisinformation_en

- Joint statement of the Members of the European Council. (2020, March 26). Retrieved from: https://www.consilium.europa.eu/media/43076/26-vc-euco-statement-en.pdf.

- Situation Report 35. (2020, February 24). WHO Coronavirus Disease 2019 (Covid-19). Retreived from: https://www.who.int/docs/default-source/coronaviruse/situationreports/20200224-sitrep-35-covid-19.pdf?sfvrsn=1ac4218d 2 


\section{WEBSITE SOURCES}

- BBC (2020, February 7), Li Wenliang. Coronavirus kills Chinese whistleblower doctor. Retreived from: https://www.bbc.com/news/world-asia-china-51403795

- Bentzen, N. (2020, May 8) European Parliament. The impact of coronavirus on media freedom. Retrieved from:

https://www.europarl.europa.eu/thinktank/en/document.html?reference=EPRS_BRI(2020)65 1905

- Darmanin, J. (2020, March 27). The Corona Virus Facts global database has doubled in a week: Check out the latest hoaxes about COVID-19. Retrieved from: https://www.poynter.org/fact-checking/2020/the-coronavirusfacts-global-database-hasdoubled-in-a-week-check-out-the-latest-hoaxes-about-covid-19/

- Davis, S. (2020, April 8). This social media post on coronavirus is full of misinformation. Retreived from: https://www.euronews.com/2020/04/08/this-social-media-post-oncoronavirus-is-full-of-misinformation.

- EEAS. (2020). European External Action Service. Retreived from: https://eeas.europa.eu/headquarters/headquarters-homepage/76341/coronavirus-news-euaction-team-europe-support-disinformation-repatriation-and-solidarity_en

- Krishan, M. (2020, May 14). Indian Muslims face renewed stigma amid COVID-19 crisis. Retrieved from: https://www.dw.com/en/indian-muslims-face-renewed-stigma-amid-covid19-crisis/a-53436462.

- Mak, T. (2020, March 16). Tech Companies Aim to Stop COVID-19 Disinformation. Retrieved from: https://www.npr.org/2020/03/16/816344301/tech-companies-aim-to-stopcovid-19-disinformation.

- Nack, C. (2020, June 11). Coronavirus prompts EU to curb spread of disinformation. Retreived from: https://www.dw.com/en/coronavirus-prompts-eu-to-curb-spread-ofdisinformation/a-53778868.

- OSCE. (2020, August). Media Freedom and Development. Retrieved from: https://www.osce.org/media-freedom-and-development.

- Wilding, M. (2020, April 25) Fighting The Infodemic: How Fake News Is Making Coronavirus Even More Dangerous. Retrieved from: https://www.esquire.com/uk/lifela32237839/fake-news-coronavirus-covid-19-infodemicl

- World Health Organisation. (2020). Infodemic management - Infodemiology. Retrieved from: https://www.who.int/teams/risk-communication/infodemic-management .

- World Press Freedom Index (2020). Entering a Decisive Decade for Journalism, Exacerbated by Coronavirus. Retrieved from: https://rsf.org/en/2020-world-press-freedomindex-entering-decisive-decade-journalism-exacerbated-coronavirus 